\begin{abstract}
A Jesuit Culture of Records? The Society of Jesus, the Life Cycle of Administrative Documents, and the Late Medieval and Early Modern History of Bureaucratic Information
\end{abstract}

Author: Markus Friedrich

Source: Engaging Sources: The Tradition and Future of Collecting History in the Society of Jesus (Proceedings of the Symposium held at Boston College, June 11-13, 2019)

Edited by: Cristiano Casalini, Emanuele Colombo, and Seth Meehan

ISBN: 978-1-947617-09-4

Published by: Institute of Jesuit Sources

Originally Published: March 1, 2021

https://doi.org/10.51238/ISJS.2019.06

Provided in Open Access by the Institute for Advanced Jesuit Studies at Boston College.

The Institute of Jesuit Sources, specializes in preserving, maintaining, and expanding for scholars around the world important texts and studies in Jesuit history, spirituality, and pedagogy.

Visit our website at https://jesuitsources.bc.edu 


\title{
A Jesuit Culture of Records? The Society of Jesus, the Life Cycle of Administrative Documents, and the Late Medieval and Early Modern History of Bureaucratic Information
}

\author{
MARKUS FRIEDRICH
}

\section{Prologue: A Broader Point}

This essay is part of a broader agenda. Together with a series of planned papers, it attempts to highlight the fact that the Society of Jesus, both in its practical modus procedendi and in its conceptual framework, had a stronger relationship to the world of late medieval Europe than is often acknowledged. Such a claim may seem to contradict prevailing interpretations, as scholarly discussions of the Jesuit order regularly highlight its forward-looking potential for change and innovation. Scholars tend to highlight those features that distinguish the Jesuits from their historical context in order to understand how they brought a "fresh wind" to Catholicism. Scholars look for innovative differences between the Society and the wider Catholic world, rather than for what made the Jesuits typical exponents of their time. Understanding the Jesuits' "distinctiveness" is, thus, a significant part of current research. ${ }^{1}$ Often enough, the founding of the Jesuit order is used as one indicator of the beginning of a new era of religious or cultural history. "The arrival of the Jesuits" often rhetorically opens a new chapter of history.

But perhaps the Jesuits combined a much stronger medieval heritage with their modernizing initiatives than is often assumed-just like Martin Luther's movement, the medieval roots of which were uncovered decades ago by Heiko A. Oberman. $^{2}$ The historians' trade lies in producing carefully nuanced accounts of how, in each individual historical moment, tradition and innovation came together. In the Jesuits' case, this means taking more fully into account the rich tradition out of which they emerged. In addition to highlighting the new beginnings that were

\footnotetext{
1 See Robert Aleksander Maryks, ed., Exploring Jesuit Distinctiveness: Interdisciplinary Perspectives on Ways of Proceeding within the Society of Jesus, Jesuit Studies 6 (Leiden: Brill, 2016). See also, directly relating to this volume, John W. O'Malley, "The Distinctiveness of the Society of Jesus," Journal of Jesuit Studies 3, no. 1 (2016): 1-16.

2 A (rather rambling) meditation on the Jesuits between medieval and modern based on strong notions of modernization theory appears in A. Lynn Martin, The Jesuit Mind: The Mentality of an Elite in Early Modern France (Ithaca, NY: Cornell University Press, 1988), 229-34. On the medieval Martin Luther, see the foundational work by Heiko A. Oberman, Luther: Man between God and the Devil, trans. Eileen Walliser-Schwartzbart (London: HarperCollins, 1993), 50-82. A strong (over)statement of the medieval origins of Luther appears in Volker Leppin, Die fremde Reformation: Luthers mystische Wurzeln (Munich: C. H. Beck. 2016), esp. 11-35.
} 
signaled by the order's founding, historians should also appreciate the more traditional features of the Society of Jesus. The Jesuits were clearly children of their time, and the Jesuit way of proceeding built on and continued social and religious practices with a long pedigree and a deep history. Often, the Society of Jesus simply extended what had been going on before. Recovering and highlighting these continuities with previous decades and generations will lead to more nuanced historical assessments of the Jesuits. Historians should complement their wellestablished understanding of the Jesuits as a creative and forward-looking force of innovation and modernization with a new emphasis on understanding the Society as an adopter and promotor of late medieval developments. This essay tries to test this idea by embedding the widely acclaimed Jesuit habit of producing and managing administrative sources into a broader context of late medieval and sixteenth-century developments in the history of administration.

\section{Introduction: Sources, Bureaucracy, Modernity}

Most publications dealing with the Society of Jesus mention at least in passing the unparalleled riches of Jesuit sources - unparalleled, that is, in comparison with other religious orders. ${ }^{3}$ The level of detail available for everyday Jesuit history is highly unusual compared with most other regular clergy. The source-friendliness of the Society, thus, often skews historiographical attention toward a Jesuit perspective, simply because it is the best-documented perspective available. No wonder, then, that Jesuit record-production and recordkeeping are frequently considered signs of Jesuit distinctiveness. The enormous amount of Jesuit paperwork testifies to their positive attitude toward the modernizing trends of bureaucratic centralization and lettered administration. ${ }^{4}$

As this paper will illustrate, however, the Jesuits were hardly alone in applying these new measures of social organization. In fact, the entire life cycle of Jesuit administrative sources-their production, storage, (re-)usage, and destruction - heavily relied upon practices and strategies first explored and widely shared decades or generations earlier. ${ }^{5}$ Without denying that the Jesuits may have

\footnotetext{
${ }^{3}$ On Jesuit sources, see, e.g., Flavio Rurale, "[...] lo sguardo o la mano del generale": Problemi e prospettive di ricerca nell'Archivum Romanum Societatis Iesu," in Gli archivi per la storia degli ordini religiosi, ed. Massimo Carlo Giannini and Matteo Sanfilippo (Viterbo: Sette Città, 2007), 93-110.

${ }^{4}$ This was my own perspective in Markus Friedrich, Der lange Arm Roms? Globale Verwaltung und Kommunikation im Jesuitenorden 1540-1773 (Frankfurt am Main: Campus, 2011).

${ }^{5}$ A similar perspective for the spheres of education and scholarship is now available in the work of Paul Nelles, see, e.g., his "Libros de papel, libri bianchi, libri papyricei: Note-Taking Techniques and the Role of Student Notebooks in the Early Jesuit Colleges," Archivum historicum Societatis Iesu 7 (2007): 75-112.
} 
indeed been great masters of bureaucratic administration, this paper highlights that they were still highly typical of their times. The historical question, then, is how the Society of Jesus used, implemented, continued, and accommodated existing traditions. From the following, highly preliminary sketch, it would appear that the Jesuits, to a very large degree, were adopters and improvers rather than inventors or creators of administrative habits and practices.

When trying to uncover the pedigree of Jesuit administrative practices, historians will have to take into account both ecclesiastical and secular traditions. In the religious sphere, it seems in many ways as if the Jesuits continued a longstanding tendency toward monastic institution-building and governance that started with the celebrated organizational achievements of the Cistercians and mendicants in the high and late Middle Ages. As much scholarship has convincingly shown, the monks and mendicants of the Middle Ages pushed paper governance to new extremes. ${ }^{6}$ How the Jesuits related to this deep history of religious organization and bureaucratic achievement, however, is still largely unexplored. ${ }^{7}$ This essay, in contrast, does not look at the medieval monastic traditions and precedents that the Jesuits may have used and elaborated on but instead highlights some secular parallels and potential precedents of the more recent past for Jesuit administrative practices.

\section{Producing Administrative Sources}

When it comes to record-production, the Jesuits were hardly the first to discover the enormous possibilities that writing brought to social organization. Both in spirit and concerning individual practices of writing, the Jesuits relied on preceding and contemporary habits. Juan Alfonso de Polanco expressly mentioned two inspirations for the Jesuit system of lettered governance: the post-Reformation

\footnotetext{
${ }^{6}$ Studies of religious organizations in the longue durée are particularly rare, and often outdated. One may refer, e.g., to Léo Moulin, Le monde vivant des religieux: Dominicains, jésuites, bénédictins (Paris: Calmann-Lévy, 1964), although the modernist bias in Moulin's historical sociology of monastic organization is quite obvious. See also David Knowles, From Pachomius to Ignatius: A Study in the Constitutional History of the Religious Orders (Oxford: Clarendon, 1966), and Knowles, Great Historical Enterprises: Problems in Monastic History (London: Nelson, 1963). A powerful and masterly survey, focusing on institutional developments of the medieval religious orders and based on decades of collaborative research, is available in Gert Melville, Die Welt der mittelalterlichen Klöster: Geschichte und Lebensformen (Munich: Beck, 2012).

${ }^{7}$ And this despite the fact that, e.g., Polanco's detailed study of other religious institutions is well known. See Alois Hsü, ed., Texts of Collectanea Polanci: Regulae aliarum Religionum (Rome: Typoskript, 1971); Hsü, "Dominican Influence on the Textual Make-Up of the Jesuit Constitutions in Regard to the Formation of Novices and the Rules for the Novice Master Based on an Unpublished Manuscript of Juan A. Polanco (1517-1576)" (PhD diss., Pontificia Università Gregoriana, Rome, 1971).
} 
Protestant networks and the early capitalist merchant houses. ${ }^{8}$ Polanco's reference to the growing importance of epistolary networks for Protestants, especially when living in small diasporas, connected the Jesuits' fascination with paper governance to a very recent and largely unprecedented phenomenon. ${ }^{9}$ Polanco's mention of mercantile bookkeeping, on the other hand, links the Society of Jesus's take on bureaucracy to paper technologies that were first tested in the fourteenth and fifteenth centuries. ${ }^{10}$ The point here is less whether or not the Jesuits actually followed the most advanced accounting routines of their time. ${ }^{11}$ The point is even less whether or not the Jesuits actually succeeded in keeping their books in order or not. ${ }^{12}$ What needs highlighting is, simply, the important point that Polanco openly, in a letter to the entire Society of Jesus, inserted his new schema of paperbased administration into a well-established, late medieval tradition that several of his brethren would have been familiar with.

In addition to Polanco's self-declared adherence to late medieval mercantile practices of communication, we may point to a number of material features of Jesuit bureaucracy in order to highlight the Jesuits' immersion in contemporary administrative culture. As is well known to every student of the Society of Jesus, the Roman curia - and to a lesser degree local and regional officials as well-relied heavily on registers to organize and keep track of much of their paperwork. The secretaries, from early on, routinely inscribed drafts of outgoing correspondence into folio codices. These registers, in particular those of the superior general's letters, were eventually organized according to geographic criteria, while a few additional special registers were kept for special issues (e.g., soli-letters). Geographical criteria also organized much of the incoming materials. This combination of the media form of register and the simple, yet straightforward

\footnotetext{
${ }^{8}$ Epp. Ign. 1, 537f.

${ }^{9}$ It is actually not easy to determine precisely what Polanco may have had in mind. He may have been thinking about the networks of Italian (and/or Spanish) (crypto)-Protestants, often connected only loosely through letters and other media. He may also have been thinking about the complex forms of communication used by dissenting groups such as the early Central European Baptists or the Waldensians in order to create community.

${ }^{10}$ For a wide-ranging and fast-paced, though somewhat uneven treatment of accounting in the context of the early modern and modern information-states, see Jacob Soll, The Reckoning: Financial Accountability and the Rise and Fall of Nations (New York: Basic Books, 2014). For a superb in-depth study of the early capitalists' paper tools, see Franz-Josef Arlinghaus, Zwischen Notiz und Bilanz: Zur Eigendynamik des Schriftgebrauchs in der kaufmännischen Buchführung am Beispiel der Datini-di-Berto-Handelsgesellschaft in Avignon (1367-1373), Gesellschaft, Kultur und Schrift 8 (Frankfurt am Main: Lang, 2000).

11 On Jesuit bookkeeping, see, e.g., Paolo Quattrone, "Accounting for God: Accounting and Accountability Practices in the Society of Jesus (Italy, XVI-XVII Centuries)," Accounting, Organizations, and Society 29 (2004): 647-83. Quattrone, "Governing Social Orders, Unfolding Rationality, and Jesuit Accounting Practices: A Procedural Approach to Institutional Logics," Administrative Science Quarterly 20 (2015): 1-35.

${ }^{12}$ For nuanced assessments, see, e.g., Dauril Alden, The Making of an Enterprise: The Society of Jesus in Portugal, Its Empire, and Beyond, 1540-1750 (Stanford: Stanford University Press, 1996).
} 
geographical ordering of records is what makes the Roman archives so effective and comparatively simple to use.

In much of this, the Society of Jesus followed established trends and adopted a bureaucratic practice that had originated much earlier elsewhere. Registers have been popular tools for managing outgoing documentation in princely chancelleries and elsewhere for a long time. ${ }^{13}$ The papacy's registers, in fact, go back at least in fragmentary form to the early Middle Ages. When, in the sixteenth century, new papal institutions started to build archives, registers were again the go-to option to organize recordkeeping. ${ }^{14}$ Earlier non-ecclesiastic parallels for the combination of registers and geographical organization can be found in the chancelleries and archives of Italian city-states or in the Habsburg government. ${ }^{15}$ Jesuit administrators thus relied heavily on the standard tools of premodern chancelleries and harnessed them in a typically late medieval and early modern drive for "centralizing the memory of decision-making."16

It would seem that the familiar breakdown of records into a provincial organization occurred only in 1573, at the beginning of Antonio Possevino's short tenure as the Society's secretary, after decades of experimentation. ${ }^{17}$ Fine-tuning the paper machinery of governance was obviously a delicate task. Finding the ideal balance of incoming and outgoing correspondence, establishing the best-suited rhythm of communication, and devising a suitably fine-grained archival organization required several decades of experimentation. The Jesuits' trial-anderror approach to improving and adjusting bureaucratic tools, not least in its rapid sequence of instructions and reforms, parallels the hectic and frequently chaotic evolution of many secular administrations. Although the Jesuits, perhaps, were unparalleled as makers of clearly articulated plans and as authors of systematic

\footnotetext{
${ }^{13}$ For a look at this important issue, see Olivier Guyotjeannin, ed., L'art médiéval du registre: Chancelleries royales et princières, Études et rencontres de l'École des Chartes 51 (Paris: École des Chartes, 2018).

${ }^{14}$ For example, in the nunciatures' archives; see Pier Paolo Piergentili, "Christi nomine invocato": La cancelleria della nunziatura di Savoia e il suo archivio, secc. XVI-XVIII, Collectanea Archivi Vaticani 97 (Vatican City: Archivio Segreto Vaticano, 2014); Michael F. Feldkamp, Die Kölner Nuntiatur und ihr Archiv: Eine behördengeschichtliche und quellenkundliche Untersuchung, Collectanea Archivi Vaticani 30 (Vatican City: Archivio Vaticano, 1993).

${ }^{15}$ For a powerful survey, see Filippo de Vivo, "Archival Intelligence. Diplomatic Correspondence, Information Overload, and Information Management in Italy, 1450-1650," in Archives and Information in the Early Modern World, ed. Alexandra Walsham and Liesbeth Corens (Oxford: Oxford University Press, 2018), 53-86. Randolph Conrad Head, Making Archives in Early Modern Europe: Proof, Information, and Political Record-Keeping, 1400-1700 (Cambridge: Cambridge University Press, 2019), 118-33, passim. Similar developments can be documented in most European regions roughly at the same time, resulting in an enormous amount of secondary literature. ${ }^{16}$ See, in connection with the tool of registers, Olivier Guyotjeannin, "Introduction," in Guyotjeannin, Art de régistre, 5-19, here 8.

${ }^{17}$ I have tried to highlight Possevino's crucial role for the Jesuits' archival practices. See Markus Friedrich, "Archive und Verwaltung im frühneuzeitlichen Europa: Das Beispiel der Gesellschaft Jesu," Zeitschrift für Historische Forschung 35 (2008): 369-403.
} 
blueprints, in terms of practical implementation they were just as inexperienced as any other administrative newcomer.

One of the driving forces behind the spread of registers as tools for recordmanagement was the enormous expansion of diplomatic services that began in the fifteenth century. Diplomatic correspondence, it seems, should be considered as a potential source of inspiration for Jesuit administrative practices. Many of the wellknown features of Jesuit epistolary habits have clear precedents in fifteenth- and early sixteenth-century ambassadorial correspondence. The custom of dividing letters into internal/secret and public/distributable ones, and more generally, of distributing different types of business to different letters or documents, emerged decades before the Jesuit governmental apparatus started working. ${ }^{18}$ A Milanese instruction from 1458 to Antonio da Trezzo, a secretary and employee of the ducal administration, may serve as an example:

We order you to make letters separate that touch upon matters of state. Do not mix them with others on particular things. [...] Remind yourself to write in such ways that the letters can be shown to whomever it may be necessary. Since some things can be shown only to this person and other things only to that, separate items into different letters or sheets. Less important things go in different letters altogether that can be shown around. ${ }^{19}$

While the language of "matters of state" is, of course, peculiar to secular administration, the Milanese logic of document-production nevertheless resembles the Jesuit agenda of distinguishing different types of bureaucratic activities that had different publics and, hence, should function in differentiated ways. Similarly, the habit of dividing letters into paragraphs — one topic, one paragraph — that makes the administrative letters such easy reading was also widely used by secular administrators. ${ }^{20}$ At first sight, such observations may seem to be only trivial minutiae when trying to evaluate the Jesuits' embeddedness in a long-lasting culture of administration. Nevertheless, as much research has very convincingly argued, it was precisely the accumulation of such small material developments in the daily practices of writing that explain many of the changes and advances in bureaucratic organization. Managing paperwork and making papers work, in fact,

\footnotetext{
${ }^{18}$ Francesco Senatore, Uno mundo de carta: Forme e strutture della diplomazia sforzesca, Mezzogiorno medievale e moderno 2 (Napoli: Liguori, 1998), 167, 233.

${ }^{19}$ Edited in Senatore, Uno mundo de carta, 430: "Te dicemo che le lettere che haveray ad scrivere che siano per facto de Stato tu le faci separate et non mixte con le altre de particulari avisi, [...], et guarda ad scrivere in tale modo che se possano monstrare ad chi bisogna, et perché una parte se poria monstrare ad uno et ad uno altro non, distinguele per diverse lettere o per policie; et le altre novelle et cose che non sono de importantia similiter scriveray per altre lettere et adaptarle in modo se posseno monstrare".

${ }^{20}$ Senatore, Uno mundo de carta, 187-89.
} 
crucially depends upon such "little tools of knowledge" like the formatting of letters, standardizing layout, or agreeing on specific document types. ${ }^{21}$

To get a better sense of where the Jesuits stood in the history of administration and administrative record-production, we may also look from an administrative point of view at some of the well-known features of the Society. Take the Jesuits' famous obsession with assessing personnel, for instance. It is clear that much of the order's attitude toward routinely evaluating new recruits as well as its members harks back to the Society's spiritual foundation in the Exercises. Besides everything else, the Exercises are a workable tool to assess individual gifts, shortcomings, and potentials. However, it is not to diminish this specifically Jesuit spirituality to point out that the order quickly transformed such spiritual soulseeking into formal and organized administrative routines and that, in doing so, the Jesuits clearly took up trends that are obvious elsewhere. ${ }^{22}$ In the Jesuit case, we may think immediately of the well-known series of catalogi (catalogs), which may (or may not) have been crucial in making decisions about which Jesuit went where and the role they would perform. Equally relevant to this question, however, are the much less-known series of Jesuit informationes, critical assessments by local fathers according to a prescribed questionnaire that were regularly created when individual Jesuits were either due to take their final vows or take over an administrative office. Not only in spirit but also in name, the Jesuit informationes somewhat resemble the papal routines for assessing candidates for episcopal sees, which also included the production of personnel assessments in the form of standardized informationes. ${ }^{23}$ What all of these administrative processes have in common is not just their reliance on similar technical tools of writing but also their overall attempt to create administrative routines, including administrative paper trails, for selecting and promoting personnel. ${ }^{24}$

The point here is not to argue for direct Jesuit take overs of preexisting, ready-made administrative and bureaucratic practices in all, or even only some of

\footnotetext{
${ }^{21}$ This refers to a now classic volume; see Peter Becker and William Clark, eds., Little Tools of Knowledge: Historical Essays on Academic and Bureaucratic Practices, Social History, Popular Culture, and Politics in Germany (Ann Arbor: University of Michigan Press, 2001).

${ }^{22}$ One well-studied case is the papal elections. See Günther Wassilowsky, Die Konklavereform Gregors XV. (1621/22): Wertekonflikte, symbolische Inszenierung und Verfahrenswandel im posttridentinischen Papsttum, Päpste und Papsttum 38 (Stuttgart: Hiersemann, 2010)

${ }^{23}$ Hubert Jedin, "Die Reform des bischöflichen Informativprozesses auf dem Konzil von Trient," in Kirche des Glaubens, Kirche der Geschichte: Ausgewählte Aufsätz; Band II; Konzil und Kirchenreform (Freiburg: Herder, 1966), 441-59. Ugo Enrico Paoli, ed., I processi informativi per la nomina dei vescovi di Trento nell'Archivio Segreto Vaticano (secoli XVII-XVIII), Annali dell'Istituto storico italo-germanico in Trento Fonti 10 (Bologna: Soc. Ed. Il Mulino, 2010).

${ }^{24} \mathrm{~A}$ comparable, though also different, case was the growing formalization (again including pretty standardized informationes) of selecting Catholic saints. On new late medieval and early modern procedures for canonization, see, e.g., Thomas Wetzstein, Heilige vor Gericht: Das Kanonisationsverfahren im europäischen Spätmittelalter, Forschungen zur Kirchlichen Rechtsgeschichte und zum Kirchenrecht 28 (Cologne: Böhlau, 2004).
} 
these cases. Although such direct take over could easily have happened, it is still difficult to prove, given the scarcity of recent work on Jesuit administration. ${ }^{25}$ What should have become obvious, nevertheless, is that Jesuit record-making and sourceproduction is best understood as belonging to a long-standing trend of administrative intensification; developments that had deep roots in the later Middle Ages. Bureaucratic centralization through lettered administration was a widely shared technology of governance not unique to the Society of Jesus. Rather, the first Jesuits simply found themselves living in a world in which such ideas and practices were already widely shared and were fast gaining additional ground. The innovation of the Jesuits, if this is what it was, was not the creation of these ideas and practices, but rather their adaptation and transfer into the realm of the regular clergy.

\section{Preserving Administrative Records}

The Jesuits mirror the administrative culture of their times not just in their continuous production of administrative records (the modern historians' "sources"); they also shared what was by then a well-established culture of archiving. Very obviously, archiving is just as important as producing documents when trying to explain and understand the characteristics and transmission of historical "sources." The history of archives has received much attention, and what becomes increasingly clear is the fact that by the mid-sixteenth century, a panEuropean trend to improve archival facilities, practices of recordkeeping, and archival consciousness in general had already been well under way for many decades. ${ }^{26}$

As is well known, first the papacy, and later the medieval monastic orders and their monasteries, had been at the forefront of recordkeeping activities since the early Middle Ages. ${ }^{27}$ In addition to the church, urban and princely

\footnotetext{
${ }^{25}$ This seems not to be a particularly prominent field in recent research activities but see, e.g., Fabian Fechner, Entscheidungsfindung in der Gesellschaft Jesu: Die Provinzkongregationen der Jesuiten in Paraguay (1608-1762), Jesuitica: Quellen und Studien zu Geschichte, Kunst und Literatur der Gesellschaft Jesu im deutschsprachigen Raum 20 (Regensburg: Schnell \& Steiner, 2015); Thomas M. McCoog, ed., With Eyes and Ears Open: The Role of Visitors in the Society of Jesus, Jesuit Studies 21 (Leiden: Brill, 2019).

${ }^{26}$ I have presented my own version of this story in Markus Friedrich, The Birth of the Archive: A History of Knowledge (Ann Arbor: University of Michigan Press, 2018 [2013]). Significant work that has appeared since includes Walsham and Corens, Archives and Information in the Early Modern World; Liesbeth Corens, Kate Peters, and Alexandra Walsham, eds., The Social History of the Archive: Record-Keeping in Early Modern Europe, Past \& Present Supplement n.s. 11 (Oxford: Oxford University Press, 2016); and Head, Making Archives in Early Modern Europe.

${ }^{27}$ Two important case-studies shed new light on this well-known fact. See Sébastien Barret, $L a$ mémoire et l'écrit: L'abbaye de Cluny et ses archives (Xe-XVIIIe siècle), Vita regularis 19 (Münster: Lit, 2004); Elke Goez, Pragmatische Schriftlichkeit und Archivpflege der Zisterzienser:
} 
administrations, too, increased their recordkeeping activities from the thirteenth century forward. The sixteenth century is currently emerging as a period of consolidation and expansion of this ongoing trend. ${ }^{28}$ Here, again, it would seem that the Society of Jesus's strong focus on archiving mirrors the era's general concerns. Following broader trends, the early Jesuits habitually displayed a keen awareness for archival questions. Georg Schurhammer illustrated how the very first attempts at recordkeeping were truly makeshift, unsystematic, and confusingly complex. ${ }^{29}$ Paul Nelles has more recently found that the year 1553 may have been a crucial moment of consolidation for Jesuit recordkeeping. ${ }^{30}$ Yet, the history of Jesuit archives continued to evolve for many decades to come. The year 1573 may have been another milestone in that history with the final establishment of the prominent series of registers.

Many Jesuit documents discuss the local, provincial, and Roman archives more or less in depth. While we now have a good understanding of the central Roman archive, knowledge about decentralized recordkeeping is still highly fragmented, although a significant number of publications discuss (or, more commonly, inventory) local and regional holdings, too. These documents show the Society of Jesus in many respects to be a rather typical exponent of broader trends in recordkeeping. Much of early modern Europe's archival culture relied on more or less consciously developed decentralized networks of archives-pace the few well-known and rightly famous attempts at archival centralization such as the Spanish crown's new central archive in the fortress of Simancas. ${ }^{31}$ The Jesuits, too,

Ordenszentralismus und regionale Vielfalt, namentlich in Franken und Altbayern (1098-1525), Vita regularis 17 (Münster: Lit, 2003). See also Thomas Hildbrand, Herrschaft, Schrift und Gedächtnis: Das Kloster Allerheiligen und sein Umgang mit Wissen in Wirtschaft, Recht und Archiv (11.-16. Jahrhundert) (Zürich: Chronos, 1996).

${ }^{28}$ Frequently (e.g., in Robert-Henri Bautier, "Histoire des archives," in L'histoire et ses méthodes, ed. Charles Samaran [Paris: Gallimard, 1961], 1121-37, and Bautier, "La phase cruciale de l'histoire des archives: La constitution des depots d'archives et la naissance de l'archivistique [XVIe-début du XIXe siècle]," Archivum 18 [1968]: 139-49), the sixteenth century is defined by the few prominent attempts at centralizing records, especially with the foundation of a central archive for the Spanish monarchy's bureaucratic offices in the fortress of Simancas in northern Spain. While this was, certainly, a key initiative, it was neither as singularly effective as often imagined nor was it a general characteristic of the time. Turning to the Jesuits, it needs to be highlighted that the Roman archive was never intended to be a central archive - it was always meant to be the archive of the order's central government, an entirely different thing.

${ }^{29}$ Georg Schurhammer, "Die Anfänge des römischen Archivs der Gesellschaft Jesu," Archivum historicum Societatis Iesu 12 (1943): 89-118. See also the famous piece by Edmond Lamalle, "L'archivo di un grande Ordine religiose: L'Archivio Generale della Compagnia di Gesù," Archiva ecclesiae 24 (1981): 89-121.

${ }^{30}$ Paul Nelles, "Jesuit Letters," in The Oxford Handbook of the Jesuits, ed. Ines G. Županov (Oxford: Oxford University Press, 2019), 44-73, here 47.

31 A classic work on Simancas is José Luis Rodríguez de Diego, ed., Instrucción para el gobierno del Archivo de Simancas (año 1588) (Madrid: Ministerio de Cultura Dir. General de Bellas Artes y Archivos, 1988). The most exhaustive (and exhausting) account may be Marc-André Grebe, Akten, Archive, Absolutismus? Das Kronarchiv von Simancas im Herrschaftsgefüge der spanischen 
relied on a systematic dispersal of records among individual houses, provincial institutions (archive of the provincial and archive of the procurator), and central Roman deposits. ${ }^{32}$ While most of this distributing happened in order to bring relevant documents to relevant officeholders, there was an additional effect of security. If a college's documents, in original and copies, were consciously spread across various sites, there remained a chance to recover at least some information should a local archive be destroyed. ${ }^{33}$

While only comparatively little information is available about the provincial archives, there is much more evidence about local Jesuit archives of colleges and other institutions. Several archives usually existed within individual houses, for instance the collections of the rector or superior, procurator, and, if applicable, of associated officials or attached institutions, such as churches or boarding houses. ${ }^{34}$ The legal and economic holdings, usually watched over by the procurator, could grow rather quickly. Already in 1611, for instance, the local (undivided) archive of the large Jesuit college-cum-university in Graz/Austria consisted of no fewer than forty-nine "drawers" or compartments ("lädl"), roughly mirroring the logic of the college's territorial possessions (witness, again, the geographical organization). ${ }^{35}$ In Graz, as in so many other colleges worldwide, the archivists continued to rely on the medieval practices of compiling cartularies to manage and safeguard the most important and legally relevant charters. ${ }^{36}$ Codices, including copiars, registers, and account-books, were but one, and a highly traditional, way to physically organize archival records. Next to handwritten books, Jesuits also used other containers for recordkeeping. In Louvain, for instance, the local archive consisted not only of "books" but also of over "six hundred sacks" full of documents plus "other papers"

Habsburger (1540-1598), Tiempo emulado 20 (Frankfurt am Main: Vervuert, 2012). Much more nuanced are the comments in Arndt Brendecke, The Empirical Empire: Spanish Colonial Rule and the Politics of Knowledge (Berlin: De Gruyter, 2016). I have traced the tension between centralizing and de-centralizing ideas about recordkeeping in the context of papal governance in my "Notarial Archives in the Papal States: Central Control and Local Histories of Record-Keeping in Early Modern Italy," Mélanges de l'Ecole Francaise a Rome 123 (2011): 443-64.

${ }^{32}$ Markus Friedrich, "Archives as Networks: The Geography of Record-Keeping in the Society of Jesus (1540-1773)," Archival Science 10 (2010): 285-98.

${ }^{33}$ See, e.g., the letter of Johann Sander, Paderborn, to Rome, March 7, 1661, asking for a search in the Roman archives for Paderborn-related materials; Johannes Sander, Geschichte des Jesuitenkollegs in Paderborn 1580-1659: Textedition und Übersetzung von Gerhard Ludwig Kneißler; Mit Anmerkungen versehen von Friedrich Gerhard Hohmann, Studien und Quellen zur Westfälischen Geschichte 64 (Paderborn: Bonifatius, 2011), 1054.

34 See, e.g., Albert Lennarz, "Das Diensthandbuch des Dürener Jesuitenrektors von 1768," Zeitschrift des Aachener Geschichtsvereins 57 (1936): 63-69, here 69.

35 Carefully described in Franz Otto Roth, "Das Granzer Jesuitenarchiv," Mitteilungen des Steiermärkischen Landesarchivs 15 (1965): 39-79.

${ }^{36}$ For an additional example, see, e.g., Johannes Krudewig, "Das Archiv der Universität und des Jesuitenkollegiums," Mitteilungen aus dem Stadtarchiv Köln 33 (1911): 49-172, here 66. 
collected under twelve "titles," perhaps in drawers or boxes. ${ }^{37}$ None of this was extraordinary, quite to the contrary. All of these physical tools for keeping, maintaining, and ordering records were standard instruments of late medieval and early modern archives. While the Jesuits' archival practices may have been extraordinary in the narrow context of the regular clergy, they were nothing but typical and standard when seen in the larger context of late medieval and early modern developments in the history of knowledge management and administration.

If the Jesuits" "ideologies" and practices of archiving essentially mirror broader trends of the age, so do many of the Jesuit archives' daily shortcomings. ${ }^{38}$ Just as everywhere else, Jesuit archiving was a mixture of success and failure. Significant amounts of Jesuit archival documents were kept sloppily or remained on the move, just as had been the case for centuries. ${ }^{39}$ One significant illustration comes from Superior General Giovanni Paolo Oliva's (in office 1664-81) long and detailed instruction of 1678 on provincial recordkeeping, which concerned itself mostly with the keeping of the general's letters and informationes in the provinces. ${ }^{40}$ Significantly, Oliva started his discussion of contemporary Jesuit archival realities with a straightforward, negative diagnosis. "Loss [iactura]" of documentation was an all-too-frequent phenomenon, the general complained. According to Oliva, archival negligence easily led to forgetting and to endangering the legal basis for possessions and privileges. Moreover, he felt that many of the provincials were not living up to the Society's standards of systematic and coherent management of affairs, not least because they neglected to maintain (and consult) their predecessor's administrative correspondence and bureaucratic documents. Archival failure came to be included in the category of disobedience and smacked of sub-standard fulfillment of official duties. Overall, this letter-which was preceded and followed by a large number of similar instructions throughout the seventeenth and eighteenth centuries - clearly mirrors the era's typical ideas and realities of recordkeeping. Equally typical, however, was also the partial failure to implement Oliva's new instructions, as demonstrated by a devastating 1686 report on the archive of the Jesuit college in Leuven. ${ }^{41}$ For all that Jesuit recordkeeping achieved, historians should not overlook the many failures and typical ineffectiveness that plagued the Society's routines of record-management. With this, they were in good early modern company.

\footnotetext{
${ }^{37}$ The following comes from Pl. Levèvre, "Une enquête sur l'état des archives du collège des PP. jésuites à Louvain en 1686," Archives et bibliothèques de Belgique 1 (1923): 97-103.

${ }^{38}$ The term "archival ideology" is an adaptation of Matthew Hull's "graphic ideology"; see Matthew S. Hull, Government of Paper: The Materiality of Bureaucracy in Urban Pakistan (Berkeley: University of California Press, 2012), 13.

${ }^{39}$ Sander, Geschichte des Jesuitenkollegs in Paderborn, 968 (Latin), 969 (German): Fr. Moritz von Büren travels with "archivio suo" through Westphalia.

${ }^{40}$ Bavarian State Library, Munich, codex latinus Monacensis (hereafter clm) 24076, fols. 112 $-113^{\mathrm{r}}$.

${ }^{41}$ Levèvre, "Une enquête sur l'état des archives," 97-103.
} 


\section{Using Records}

Not every document produced was properly archived, and certainly not every archived document was actually used by administrators. Disentangling production, preservation, and actual usage of documents is a key result of recent scholarship. However, if the production of documents (and their archivization) was not necessarily leading to actual usage, we may have to reassess the realities of supposedly ultra-bureaucratic organizations such as the Jesuit order. In order to historicize Jesuit sources properly, we thus need to evaluate the status of specific record types in their historical contexts. How important were certain documentsour sources - for early modern Jesuits? How did they view the different categories of documents? What was the Jesuit communities' attitude toward, for instance, the constant drum of missionary reports, given their curious mixture of exciting details and predictable tone - were early modern Jesuits really listening to them as eagerly as modern historians read them? Which documents had which relevance for Jesuit decision-makers? Did the routines of decision-making actually mirror the hierarchies of communication? What can we say about the day-to-day impact of famous documents-types like the catalogi or the many letters in which individual Jesuits offered themselves for missionary service (indipetae)?

There are of course impressive examples of seemingly effective procedures of record-usage. When embattled, many fathers simply went to their archive and "brought out the authentic documents" required to settle legal disputes. ${ }^{42}$ Nevertheless, research has also produced ample evidence that certainly not every bit of administrative writing directly or indirectly affected Jesuit decision-making or effected specific policies. ${ }^{43}$ What the Jesuit documents-now understood as "sources" - tell us today may not have been what they told their intended audiences. Historians should carefully reconstruct the historical impact of sources when trying

\footnotetext{
42 "Produximus documenta authentica"; see Christoph Flucke and Martin Schröter, eds., Die litterae annuae: Die Jahresberichte der Gesellschaft Jesu aus Altona und Hamburg (1598-1781) (Münster: Aschendorff, 2015), 496.

${ }^{43}$ The litterae indipetae are a good example here. So far, they have mostly been read for what they tell us about individual Jesuits' missionary feelings; see, e.g., Gian Carlo Roscioni, Il desiderio delle Indie: Storie, sogni e fughe di giovani gesuiti italiani, Saggi 837 (Turin: Einaudi, 2001). Only very recently have researchers started to look more in depth into the Roman administrative reactions to the incoming letters; see esp. Elisa Frei, "The Many Faces of Ignazio Maria Romeo, S.J. (16761724?), Petitioner for the Indies: A Jesuit Seen through his Litterae indipetae and the Epistulae generalium," Archivum historicum Societatis Iesu 85 (2016): 365-404. See also Frei, “"In nomine Patris': The Struggle between an Indipeta, His Father, and the Superior Generals of the Society of Jesus (ca. 1701-1724)," Chronica mundi 13, no. 1 (2018): 107-23. For a good, general introduction to the indipetae, see Emanuele Colombo and Marco Rochini, "Four Hundred Years of Desire: Ongoing Research into the Nineteenth-Century Italian Indipetae (1829-1856)," in Representations of the Other and Intercultural Experiences in a Global Perspective (16th-20th Centuries), ed. Niccolò Guasti, History 4 (Sesto San Giovanni: Mimesis International, 2017), 83-108.
} 
to assess their relevance for historical actors. Only after gaining clarity about the documents' historical impact can questions concerning the Jesuits' degree of bureaucratization be fully answered.

Finding evidence about the historical impact of documents is difficult. Writing about using documents is usually not a primary concern, even in bureaucratic cultures. There are, nevertheless, clear signs of a Jesuit culture of using and reusing documents. There exist, for instance, numerous "secondary" sources that help us trace Jesuit practices of document usage. "Secondary" are documents or genres of documents that existed in order to make "primary" sources relevant on a daily basis - administrative notebooks, personal compilations of regulations, and office-related manuals of successful working practices. Such personalized and locally specific forms of compilations helped to condense the vast body of official documentation and helped target it to site- and office-specific goals. In selecting and compressing the indigestible wealth of past and current bureaucratic paper trails, such "secondary sources" pared down the enormous number of official records. Selecting the most important and relevant pieces of Roman instructions, for instance, endowed an otherwise indigestible archive with practical meaning and made it useable. Alessandro Valignano compiled a highly extensive collection of excerpts from the superior generals' letters in Asia, which may serve as an example. ${ }^{44}$ Valignano condensed the voluminous correspondence coming in from Rome in a way that made it useable for him in his daily tasks. Similar compilations existed throughout the Jesuit world. There was, inevitably, something personal, and perhaps even idiosyncratic, to creating such compilations, even though the curia also attempted to standardize such compendia. These local notes, therefore, are not primarily interesting for their actual content, as the original letters are often still available in the Roman documents (although they may have preserved the odd letter otherwise lost); rather, they show forcefully how local actors went about using the vast ocean of Jesuit documents. Using Jesuit records, for local members of the order, meant selecting and "localizing" the continuous stream of internal correspondence.

Actual usage of documents can also be assessed through processes of ongoing rewriting. There is evidence of cross-referencing, for instance, that links annual letters or house histories back to local diaries from ministers or procurators. ${ }^{45}$ These records were known, consultable, and accessed when necessary. Moreover, signs of at least a limited culture of consciously improving outdated or wrong information exist. David Aeby, in a $2019 \mathrm{PhD}$ thesis, has presented an interesting example of a diarium of Fribourg's college minister that a

\footnotetext{
44 DocInd. 10, 568-647.

45 For one example ("Vide librum cotidianarum [...] Procuratoris"), see Sander, Geschichte des Jesuitenkollegs in Paderborn, 1008.
} 
later minister mined to find precedences for a liturgical event. The second minister, then, entered a personal note into his predecessor's notation. ${ }^{46}$ In such ways, Jesuit administrative documents were almost living and learning documents. Along these lines, in 1678 Superior General Oliva ordered that superiors should correct letters containing misleading information by annotating them. ${ }^{47}$ If that was graphically not feasible, they should pin small slips of paper to the offending document and write their corrections on these. Here, again, we see Jesuit documents being reused and rewritten. At least to some degree, the Jesuit handling of administrative documentation called for continuous engagement with the paper trail, not least through processes of retraction, redaction, and refashioning of documents.

It is still a largely open question if there is something like a distinctive Jesuit approach to using and applying administrative documentation. ${ }^{48}$ Whether or not Jesuits more easily took advantage of their archival treasures than their contemporaries is still open for investigation. As far as we can see so far, the Jesuits seem to display a typical ambivalence: as in many other late medieval and early modern organizations, there was potential for effective and powerful deployment of archived papers, but we should not expect this potential to have been activated all too frequently. In all likelihood, the Jesuits, too, had to make significant efforts to engage meaningfully with their stored documents, something that often only occurred ad hoc.

\section{Black Holes in the Jesuit Records: Destructions and Other Lacunae}

Work on the history of (state) information has started to pay increasing attention to the phenomena of destruction, forgetting, and neglect. ${ }^{49}$ The Society of Jesus, too, was not only a great producer and manager of written documentation; its records also suffered serious losses, and for various reasons. Again, the Jesuits seem to be very much a child of their times. Locally, Jesuit documents were just as prone to destruction through natural or man-made disaster as all other papers. ${ }^{50}$ The Thirty Years' War (1618-48), for instance, brought devastation to many a Central

\footnotetext{
${ }^{46}$ David Aeby, "La Compagnie de Jésus de part et d'autre de son temps de suppression: Les jésuites à Fribourg en Suisse au XVIII et XIX ${ }^{\mathrm{e}}$ siècle" (PhD diss., Faculté des Lettres de l'Université de Fribourg, 2019), pp. 255f.

${ }^{47}$ See clm 24076, fol. $112^{\mathrm{v}}$.

${ }^{48}$ I leave aside here the equally important, though equally understudied question of Jesuit historiography and its reliance on internal documentation. Much would be gained from a clearer understanding of how Jesuits' created historiography about themselves from existing internal records.

${ }^{49}$ Konrad Hirschler, "From Archive to Archival Practices: Rethinking the Preservation of Mamluk Administrative Documents," Journal of the American Oriental Society 136 (2016): 1-28.

${ }^{50}$ See, e.g., the remark about missing annual letters in central and northern Germany in Sander, Geschichte des Jesuitenkollegs in Paderborn, 472 (Latin), 473 (German).
} 
European Jesuit archive. ${ }^{51}$ In addition, the suppressions of the Society of Jesus brought serious disruption to Jesuit recordkeeping practices, a process still only rudimentarily understood.

The Jesuits themselves also orchestrated campaigns of record-destruction. There has been widespread speculation about a purge of the Roman registers after the memorialistas-crisis under Superior General Claudio Acquaviva (in office 1581-1615), for instance. If this ever happened, it would seem to have been a deliberate act of ideologically aligning the archive with the winner's side in a complex internal battle. Other, less sinister forms of purging the record occurred, however. There exist hardly any incoming letters in Rome any more, certainly not from around 1600 onward. While the generals' outgoing letters appear more or less complete in the Roman registers, the received correspondence was obviously deemed irrelevant after a certain point in time. This is entirely at odds with the practices of other contemporary administrations, which often tried to transform their archive of incoming letters into a more or less workable "encyclopedia" of the current world and its status quo. Similar practices prevailed at the provincial levels, too. One of the most interesting instructions for the systematic purging of the administrative record appears in the above-mentioned instruction on archiving from Oliva (1678). In explicit terms, he recommends that outgoing provincials withdraw and "burn" materials that might concern the new, incoming team of provincial and socius personally. "In order to maintain peace and unity among superiors and subjects," so the instruction states, all documents potentially offending to the new administrators needed to be cleared out before their tenure started. The outgoing provincial should collect other materials of the same kind, put them under lock and seal, and "in the name of Father General, he [the outgoing provincial] should deny the incoming team permission to open these bundles." 52 There seemingly existed a close connection between counter-archival practices and the maintenance of social peace.

Furthermore, only small fragments of intra-provincial communication have survived the times. There must have existed large bodies of epistolary exchanges, for instance between procurators of different houses. In addition, rectors and superiors would have communicated with their provincials, and vice versa. In many Jesuit archives, only small quantities of this presumably once voluminous material remain. Much of this may be a result of the events of 1773 , but in part this may also be a sign that parts of the Jesuits' records were just not as systematically kept as is often assumed.

\footnotetext{
${ }^{51}$ See once more the letter of Johann Sander, Paderborn, to Rome, March 7, 1661, indicating significant losses due to earlier warfare; Sander, Geschichte des Jesuitenkollegs in Paderborn, 1054.

${ }^{52}$ See clm 24076, fol. $112^{\mathrm{v}}$.
} 
In any case, the relative dearth of intra-provincial documentation seems to have led to a certain neglect of regional approaches in current Jesuit historiography. Archive-based in-depth studies of regional Jesuit networks and activities are much less common than studies focusing on individual cities or institutions, often highlighting the direct link between local houses and Rome. ${ }^{53}$ This seems to mirror the relative lack of Jesuit sources explicitly discussing and substantiating such regional approaches in contrast with the richness of Roman and local sources on individual locations. Yet there may very well have been a stronger regional dimension to Jesuit identity and cooperation than appears from our sources. The dearth of intra-provincial sources, wherever it may come from, however, makes it much harder to recover this dimension of early modern Jesuit life.

A final and slightly more speculative point concerning the lacunae of Jesuit records: fascinated as they were by the prospects of subjecting everyday life to an ever more complex system of bureaucratic writings, the Jesuits also carefully limited lettered administration and restricted government by paper. The Society of Jesus - and the Catholic Church at large - created or at least protected a sphere of orality in the midst of all the paperwork. The confession, and everything related to it, is only the best example. Not only did it need to be secret and protected but also oral and aural. There was generally significant skepticism toward all attempts at written confession, especially toward epistolary confessions. Other crucial spiritual practices, including the brotherly correction (correctio fraterna), the rendering of conscience (ratio conscientiae), and much of the Spiritual Exercises, too, were mostly oral. Thus, for some of the most central elements of daily Jesuit life, we are by default lacking sources, as they were never subjected to writing. Important parts of Jesuit history, thus, remain largely hidden from historians' probing eyes. Maintaining, indeed creating and protecting, curating and nurturing a certain form of orality, may be seen as a crucial reaction to an ever-growing presence of writing, whether in manuscript or print. Paula McDowell, in her book The Invention of the Oral (2017), argues precisely this point. Orality, McDowell concludes, emerged as a form of communication worthy of defense only once people began to feel dominated by the written word. ${ }^{54}$ While McDowell's argument mostly concerns the eighteenth century and is thus not easily applicable to earlier periods, it is nevertheless clear that at least some Jesuits in the sixteenth century already saw these spheres of orality as particularly in need of protection, given what they considered to be an ever-growing reliance on written forms of governance. Not for nothing, it seems, were the memorialistas rebelling against the rise of lettered

\footnotetext{
${ }^{53}$ Important exceptions include, e.g., Paul Shore, Jesuits and the Politics of Religious Pluralism in Eighteenth-Century Transylvania: Culture, Politics, and Religion, 1693-1773 (Aldershot: Ashgate, 2007).

${ }^{54}$ Paula McDowell, The Invention of the Oral: Print Commerce and Fugitive Voices in EighteenthCentury Britain (Chicago: University of Chicago Press, 2017).
} 
governance as an attack on the time-honored forms of personal and conversational, oral and aural religious interaction.

From these observations, historians may in the future start to consciously mine the Jesuit records for signs of and information about non-written forms of communication. ${ }^{55}$ Perhaps the Jesuit sources provide at least an occasional window into the important sphere of oral exchange, of correction, encouragement, or counseling through personal communication. Gossip, too, certainly also flowed through the aisles of Jesuit institutions, and this highly fleeting form of oral exchange, too, should attract Jesuit historians. ${ }^{56}$

\section{Conclusion}

Assessments of continuity and change in history inevitably rely on the historian's judgments about what should, and should not, be considered historically important. Both "continuity" and "change" are assessments ex post, not objective states of being. It is historians (and contemporaries) who highlight one or the other. "Change" or "continuity" is a narrative pattern that frames historiographical presentation. In the case of Jesuit historiography, much of the predominant narrative is one of "new beginnings" and "change." Such a bias serves a series of historiographical agendas, as a robust conviction of Jesuit newness underpins the notion that religious life changed significantly in the Reformation and postReformation era. As such, it helps to establish and support the notion that sixteenthcentury Christianity, both Catholic and Protestant, underwent a crucial process of modernization. While this may not be entirely wrong, it still underestimates and underappreciates the more "medieval" features that continued to persist. At the very least, therefore, the habitual insistence on Jesuit newness and distinctiveness should be balanced by references to those areas of Jesuit history where the new order clearly continued existing traditions and practices.

This paper has attempted to recalibrate ideas about the newness and distinctiveness of the Society of Jesus by focusing on Jesuit administration and record management. As it turns out, the Jesuits were just as often adapting existing practices as they were inventing new ones. Our discussion clearly shows the Jesuits to be receptive observers of what was going on around them. They seem to have been especially apt at repurposing existing and well-tested routines to their own goals, in the process making any number of adjustments, thus harnessing broader

${ }^{55}$ For an example of how to do this, see Filippo de Vivo, "Archives of Speech: Recording Diplomatic Negotiation in Late Medieval and Early Modern Italy," European History Quarterly 46 (2016): 519-44.

${ }^{56}$ For an instructive example, see, e.g., Alison Shell, Oral Culture and Catholicism in Early Modern England (Cambridge: Cambridge University Press, 2009). 
trends for their specific needs. The sensible question to ask is not whether the result was "new" or not, whether Jesuit administration amounted to a "change" (or even a "revolution") in the history of religious life. Rather, historians should historicize the experience and practice of the premodern Jesuits by highlighting that they, just like every human being and organization, accommodated existing social practices while trying to live-up to their self-declared goals in life. There certainly was great uniqueness in the way the Jesuits built an administrative life out of the existing possibilities, even though it is also clear that this was, to a large degree, as much a bricolage of existing features as a creatio ex nihilo. 